\title{
Leder
}

\section{Temanummer om styring av naturressurser}

\section{May Thorseth \& Siri Granum Carson}

Dette nummeret av Etikk i praksis - Nordic Journal of Applied Ethics er et temanummer om styring av naturressurser. Den tematiske delen inneholder tre artikler, mens den åpne delen har to artikler som drøfter svært dagsaktuelle tema.

Styring av naturressurser er et stort tema som potensielt kan inneholde mange ulike problemstillinger, som ansvarlig forvaltning av felles ressurser, bærekraftig ressursutnyttelse, global, rettferdig styring av nødvendige fellesgoder og mye mer. Sentrale spørsmål er hvem som skal ha rett til å styre og forvalte ressursene, og hvordan tilgangen på naturressurser påvirker institusjoner og politikk. Forholdet mellom i-land og u-land samt forholdet mellom generasjonene er viktig i diskusjonen om rettferdig styring av naturressurser. De tre artiklene i dette temanummeret dekker noen av disse områdene.

I den første artikkelen, «People's right to self-determination and self-governance over natural resources: Possible and desirable?», reiser Hans Morten Haugen spørsmålet om hvorvidt sterkere lokal selvstyring av naturressurser bør foretrekkes. Et viktig argument for sterkere lokalt selvstyre er basert på anerkjennelse av urfolks rett til selvbestemmelse sammen med fritt og informert samtykke fra de berørte. En problemstilling i denne artikkelen gjelder forståelsen av allmenningens tragedie - «tragedy of the commons» - som beskrevet av Garrett Hardin. Artikkelforfatteren argumenterer for at allmenningen er avhengig av grenser, og at Hardins allmenning snarere beskriver et «free-for-all»-regime enn en allmenning. Elinor Ostroms designprinsipper for «common-pool resources» står sentralt. Artikkelen konkluderer med at retten til selvbestemmelse har en eksplisitt naturressursdimensjon, og at det fins et uutnyttet potensial for at menneskerettighetene kan påvirke styringen av naturressurser.

Mens den første artikkelen ser på naturressurser mer generelt, og deres betydning for retten til helse, mat og vann spesielt, fokuserer Jennifer Bailey i neste artikkel, «Looking for sustainable solutions in salmon aquaculture», på oppdrettslaks i Atlanterhavet. Hovedpoenget i denne artikkelen er å illustrere hvor omfattende, komplekse og sammenvevde problemer knyttet til bærekraftighet denne industrien har å jobbe med. Med utgangspunkt i triaden miljøaspekter, sosiale aspekter og økonomiske aspekter ved bærekraft konkluderer Bailey med at det finnes et behov for komplekse og mangfoldige beslutningsstrukturer i oppdrettsnæringen. På bakgrunn av saken som diskuteres i artikkelen - oppdrettsnæringen for Atlanterhavslaks -, foreslår forfatteren fire sentrale strukturer for å styrke bærekraftighet. Disse diskuteres med bakgrunn i to ulike kontekster: Chile og Norge. De fire dimensjonene som identifiseres, er (1) demokratisk system på nasjonalt nivå, (2) det sivile samfunn som arena for forhandling mellom interessenter (stakeholders), (3) markedets beslutningsmåter (som kan påvirkes av WWF) samt (4) NGO-er, internasjonale organisasjoner og nettverk som pådrivere for å fremme bærekraftighet. 
Eksempler på slike organisasjoner er Convention on Biodiversity, Agenda 21 og FAO. Samspillet mellom de fire dimensjonene er avgjørende for bærekraftig utvikling i ulike kontekster, som for eksempel henholdsvis Chile og Norge.

I den tredje artikkelen om styring av naturressurser - «Governance of mineral resources: Towards the end of national states supremacy?» - tar Fanny Verrax for seg en helt annen naturressurs, nemlig mineraler som hører til gruppen sjeldne jordmetaller (rare earth elements, REE). Dette er metaller som er spesielt viktig for utvikling av ny og mer miljøvennlig teknologi, som harddisker, flatskjermer for TV, mobiltelefon og PC-er samt grønn teknologi, som vindturbiner og batterier for hybridbiler. Mesteparten av utvinningen av disse metallene foregår i Kina, og 97 prosent av eksporten av REE kontrolleres av Kina, som nå har bestemt at de skal redusere eksporten av disse metallene. Et viktig spørsmål i artikkelen er hvorvidt det rådende styringsregimet og WTO / globale handelsavtaler basert på nasjonalt ansvar og kontroll over ressursene er tilpasset bærekraftig og rettferdig håndtering av disse mineralressursene. Forfatteren argumenter for at så ikke er tilfelle når det gjelder knappe, ikke-fornybare og ujevnt fordelte ressurser som REE spesielt. Mot slutten av artikkelen fremmer forfatteren forslag til to alternative veier mot bedre styring av slike naturressurser.

I den åpne delen av tidsskriftet har vi to artikler som begge dreier seg om den teknologiske utviklingen innenfor helsevesenet og de etiske utfordringene en slik utvikling bringer med seg. I den første, «Retten til privathed i det danske sundhedsvæsen», beveger vi oss inn i en pågående debatt i Danmark om den økende digitaliseringen og delingen av personopplysninger i helsevesenet - en diskusjon som også pågår i mange andre land, deriblant i Norge. Utviklingen i retning av digitalisering kan gi medisinske gevinster ved at viktige helseopplysninger blir lettere tilgjengelig i krisesituasjoner, og kan også være ressurs- og kostnadsbesparende. Samtidig innebærer denne utviklingen etiske utfordringer for den enkelte borger, knyttet til autonomi og trusselen mot retten til privatliv. I denne artikkelen diskuterer Hanne Pihl Bjerre og Katrine Juel Vang disse utfordringene innenfor rammen av en konkret kontekst, nemlig innføringen av Det Foelles Medicinkort i Danmark.

I den siste artikkelen i dette nummeret, «Etiske utfordringer med non-invasive prenatale tester (NIPT)», redegjør Bjørn Hofmann for utviklingen innenfor feltet fosterdiagnostikk. Non-invasive prenatale tester (NIPT) gjør det mulig å analysere cellefritt DNA fra foster i gravide kvinners blod. Dette er i utgangspunktet tryggere og bedre tester enn de eksisterende testene, men de reiser også en rekke etiske problemstillinger. Hofmann gjør i artikkelen rede for flere slike problemstillinger og identifiserer fem spørsmål som bør diskuteres grundig før NIPT innføres som standard helsetilbud i Norge - deriblant hvilke tilstander man skal søke etter (og fjerne), og hvordan testene kan implementeres uten å diskriminere eller stigmatisere de som har tilstandene som søkes etter (og fjernes). Moderne fosterdiagnostikk kan gi bedre svangerskapsomsorg og nyfødtmedisin, men aktualiserer også en rekke grunnleggende etiske spørsmål rundt abort og fostres moralske status. 